\title{
Transport Device
}

National Cancer Institute

\section{Source}

National Cancer Institute. Transport Device. NCI Thesaurus. Code C50233.

Any device designed to move something. 